\title{
Germination of Fusarium graminearum Ascospores and Wheat Infection are Affected by Dry Periods and by Temperature and Humidity During Dry Periods
}

\author{
V. Manstretta, C. Morcia, V. Terzi, and V. Rossi
}

First, second, and fourth authors: DI.PRO.VE.S. Department of Sustainable Crop Production, Università Cattolica del Sacro Cuore, Piacenza, Italy; and second and third authors: CRA-GPG, Council for Agricultural Research and Economics, Genomics Research Centre, Fiorenzuola d'Arda (PC), Italy.

Accepted for publication 23 November 2015.

\begin{abstract}
Manstretta, V., Morcia, C., Terzi, V., and Rossi, V. 2016. Germination of Fusarium graminearum ascospores and wheat infection are affected by dry periods and by temperature and humidity during dry periods. Phytopathology 106:262-269.

The effects of temperature and relative humidity $(\mathrm{RH})$ on germination of Fusarium graminearum ascospores, and of dry periods (DP) of different lengths and of temperature and RH during DP on ascospore survival were studied both in vitro and in planta. Optimal temperatures for ascospore germination at $100 \% \mathrm{RH}$ were 20 and $25^{\circ} \mathrm{C}$; germination was $\leq 5 \%$ when ascospores were incubated at $20^{\circ} \mathrm{C}$ and $\mathrm{RH} \leq 93.5 \%$. Viable ascospores were found at all tested combinations of DP duration (0 to $48 \mathrm{~h}) \times$ temperature $\left(5\right.$ to $\left.40^{\circ} \mathrm{C}\right)$ or $\mathrm{RH}(32.5$ to $100 \% \mathrm{RH})$. Germination
\end{abstract}

ABSTRACT declined as DP duration and temperature increased. Germination was lower for ascospores kept at $65.5 \% \mathrm{RH}$ during the DP than at 76.0, 32.5, or $93.5 \%$ RH. Equations were developed describing the relationships between ascospore germination, DP duration and temperature or RH during DP. Durum wheat spikes were inoculated with ascospores and kept dry for 0 to $48 \mathrm{~h}$ at approximately $15^{\circ} \mathrm{C}$ and $65 \% \mathrm{RH}$; plants were then kept in saturated atmosphere for $48 \mathrm{~h}$ to favor infection. Fungal biomass, measured as $F$. graminearum DNA by quantitative polymerase chain reaction, declined as DP increased to 24 and $48 \mathrm{~h}$ at 3 and 9 days postinfection but not in spikes at maturity.

Additional keywords: Fusarium head blight, Gibberella zeae, modeling, spore survival.
Fusarium graminearum Schwabe produces sexual spores (ascospores) and asexual spores (macroconidia). The sexual form of F. graminearum is Gibberella zeae (Schwein.) Petch. In this work, we refer to F. graminearum following the "one fungus one name" provision (Geiser et al. 2013; Hawksworth 2011). Several reports indicated that ascospores may be more important than macroconidia for Fusarium head blight (FHB) epidemics (Fernando et al. 1997; Osborne and Stein 2007; Sutton 1982). Ascospores are produced on previous crop debris in the field, such as maize residues (Khonga and Sutton 1988; Pereyra et al. 2004), and are then forcibly discharged into the air from perithecia (Trail et al. 2002). They can initiate infection after traveling short distances (de Luna et al. 2002; Fernando et al. 2000; Keller et al. 2010; Markell and Francl 2003; Paulitz 1996) and also long distances (Del Ponte et al. 2003; Francl et al. 1999; Maldonado-Ramirez et al. 2005; Prussin et al. 2014a, b; Schmale et al. 2012).

The environmental conditions favoring the formation of perithecia and the discharge of ascospores (Inch et al. 2000; Manstretta and Rossi 2015a, b; Paulitz 1999a, b; Trail et al. 2002; Tschanz et al. 1976) as well as their germination (Beyer and Verreet 2005; Gilbert et al. 2008; Sung and Cook 1981) have been well studied. These processes are greatly affected by relative humidity $(\mathrm{RH})$ (Jennings and Turner 1996; Xu 2003). Studies on ascospore germination have consistently indicated that ascospore germination is maximal at high $\mathrm{RH}$ (from about 84 to $100 \%$ depending on the report) and that the germination rate rapidly diminishes as RH declines below these levels; according to the literature, no germination occurs below 50 to

Corresponding author: V. Rossi; E-mail address: vittorio.rossi@unicatt.it
55\% RH (Beyer et al. 2005; Beyer and Verreet 2005; Sung and Cook 1981; Ye 1980).

Processes leading to ascosporic infection (development and maturation of perithecia, ascospore ejection, and ascospore germination) are then all strictly dependent upon high environmental humidity. Ascospores are usually ejected from perithecia under wet conditions provided by rainfall or atmospheric humidity (Manstretta and Rossi 2015b). After becoming airborne, ascospores eventually settle on the surface of a spike and germinate within a few hours if humidity is high (Beyer and Verreet 2005). Therefore, ascospore discharge seems to preferentially occur when humidity conditions for germination are favorable. Nevertheless, ascospores may be deposited on wheat spikes when humidity is unfavorable for germination if any of the following occur: (i) ascospores are ejected from perithecia significantly after the ejection has been triggered by moisture (Manstretta and Rossi 2015b) so that some of the ascospores become airborne under dryer conditions; (ii) a portion of the seasonal ascospores are discharged and dispersed under dry conditions (Manstretta and Rossi 2015b); or (iii) there is a time lag between ascospore ejection and deposition (Schmale et al. 2006).

As a consequence of these three possibilities, $F$. graminearum ascospores can be recovered from spikes on every day regardless of moisture conditions (Francl et al. 1999). Ascospores present on the spikes under unfavorable humidity conditions for germination may survive until the next period of high humidity favors germination. Little and ambiguous information is available on the time ascospores remain viable once they have been discharged from the perithecium. Jin et al. (2001) found that the ascospore germination rate declined rapidly within 12 days. Beyer and Verreet (2005) observed that ascospores lost their viability after being discharged from perithecia and detected significant portions of nonviable ascospores within a few days after discharge. Schmale and Bergstrom (2004) found 
significant viability of ascospores on both artificial (plastic) and real wheat spikes after 3 days of exposure in natural environments. Similarly, Francl (1998) observed that ascospores remained viable on spikes for about $48 \mathrm{~h}$. Some ascospores were found to retain their viability for a considerable length of time after discharge from the perithecium (Beyer and Verreet 2005; Schmale et al. 2006).

Effect of relativity humidity on ascospore survival is unclear. Beyer and Verreet (2005) found that ascospores lost their ability to germinate when exposed to $0 \% \mathrm{RH}$ for $1 \mathrm{~min}$, and incubation of ascospores at $53 \% \mathrm{RH}$ decreased the percentage of viable spores from 93 to $6 \%$ within $10 \mathrm{~min}$. In contrast with this drastic effect of RH, Gilbert et al. (2008) reported that ascospores exposed at 30, 60, and $90 \% \mathrm{RH}$ for 4 to $48 \mathrm{~h}$ were still able to germinate on water agar, even though germination rates fell when temperature increased between 15 and $30^{\circ} \mathrm{C}$; the lowest rate of germination, $13 \%$, occurred after $48 \mathrm{~h}$ of incubation at $30^{\circ} \mathrm{C}$ and $60 \% \mathrm{RH}$.

As indicated in the previous paragraph, information on how environmental conditions affect ascospore viability is ambiguous and incomplete. Relevant questions remain unanswered. What is the viability at temperatures lower or higher than those tested by Gilbert et al. (2008)? What are the dynamics of viability when ascospores are exposed to dryness (i.e., periods with low $\mathrm{RH}$ ) for durations between 4 and $48 \mathrm{~h}$ (which were the only two durations considered by Gilbert et al. [2008]), i.e., for those dry periods (DP) that usually occur in the normal daily pattern of RH (Peixoto and Oort 1996)? Does the reduction in ascospore viability in vitro reflect the reduction in infection severity in planta? Answering these questions should improve epidemiological models and lead to new approaches for controlling the disease.

The objectives of this study were to (i) quantify the survival of $F$. graminearum ascospores as affected by temperature, $\mathrm{RH}$, and exposure duration by considering a broader range of conditions than in the previous published works; and (ii) assess the effect of DP on ascospores after their deposition on wheat spikes by means of in planta trials.

\section{MATERIALS AND METHODS}

Preparation of ascospore suspensions. Two strains of $F$. graminearum were used; one was isolated from wheat kernels in Italy (Emilia-Romagna) (Università Cattolica del Sacro Cuore, Piacenza, Italy), and the other was isolated from oat kernels in Germany (Institut fur landwirtschaftliche Kulturen, Bundesanstalt fur Zuchtungsforschung an Kulturpflanzen, Sanitz, Germany). These strains where maintained on $1.5 \%$ water agar at $4^{\circ} \mathrm{C}$. Small plugs of agar were transferred to the center of 60 -mm-diameter plates containing carrot agar (Klittich and Leslie 1988) and incubated at $20^{\circ} \mathrm{C}$ in the dark until the fungi had completely colonized the agar surface (in 5 to 7 days). After the aerial mycelium was gently removed with a sterile metal rod, $1 \mathrm{ml}$ of an aqueous solution (2.5\%) of Tween 20 (Sigma-Aldrich, St. Louis, MO) was uniformly spread on the agar surface. The plates were then covered with the lid but not sealed (to allow air circulation) and incubated at $20^{\circ} \mathrm{C}$ with a 12-h light/12-h dark photoperiod; a mixture of white and UV light was used to induce perithecia.

After 14 days, the perithecia were mature and were individually transferred with a needle to a tube containing $1.5 \mathrm{ml}$ of water. The suspension of perithecia was mixed with a vortex apparatus to allow mature ascospores to exit from perithecia and become suspended in the water. The suspension was then passed through a sterile, single layer of cheesecloth to remove the perithecia. The concentration of ascospores in the suspension was determined with a Bürker hemocytometer and was adjusted to $2 \times 10^{4}$ ascospores $/ \mathrm{ml}$. Separate ascospore suspensions were prepared for each fungal strain for the in vitro experiments, while equal amounts of the two single-isolate suspensions were mixed for the in planta experiments. Microscopic examination confirmed that ascospores in the suspensions had not germinated at the initiation of these experiments.
In vitro experiments. Two types of experiments were performed to study (i) the effect of temperature (temp) and RH on the germination of $F$. graminearum ascospores, and (ii) the effect of ascospore exposure to DP that differed in length, temperature, and $\mathrm{RH}$ on ascospore survival. Both experiment types were run three times. In all experiments and replicate runs, germination of ascospores was observed on microscope slides as previously done by Gilbert et al. (2008).

Effect of temperature. Drops $(20 \mu \mathrm{l}$ each) of the ascospore suspension of each of the two fungal strains were placed on microscope slides (three drops per slide) and dried in a laminar flow cabinet. The slides were kept in the cabinet just long enough to allow the drops to dry. The ascospores on the slides were examined at the end of this drying phase, and none had germinated. The microscope slides were then moved from the laminar flow cabinet and arranged in Petri dishes (94 $\mathrm{mm}$ diameter, one slide per dish) over a wet blotting paper.

To study the effect of temperature on ascospore germination in a saturated atmosphere, the dishes were placed in incubators at $100 \%$ $\mathrm{RH}$ and at $5,10,15,20,25,30,35$, or $40^{\circ} \mathrm{C}$ for $24 \mathrm{~h}$. To study the effect of time on ascospores germination, the dishes were incubated at $100 \% \mathrm{RH}$ and $20^{\circ} \mathrm{C}$ for $3,6,12$, and $24 \mathrm{~h}$ (dishes to be checked at these different times were arranged in the incubator according to a complete randomized design). Germination was assessed using a light microscope (200× magnification) for 600 ascospores per treatment, resulting from two slides $\times$ three drops per slide $\times 100$ randomly chosen ascospores per drop; a treatment is defined as the combination of one incubation temperature, or one incubation time, $\times$ two fungal strains. An ascospore was scored as germinated if at least one germ tube was clearly visible.

To study the effects of temperature on germination during DP of varying lengths, microscope slides were arranged in Petri dishes over a dry blotting paper and incubated at $60 \% \mathrm{RH}$ and $5,10,15,20$, $25,30,35$, or $40^{\circ} \mathrm{C}$ for DP of $0,3,6,9,12,24$, or $48 \mathrm{~h}$ (dishes to be checked at these different times were arranged in the incubator according to a complete randomized design); $60 \% \mathrm{RH}$ was chosen as the baseline for DP and temperature evaluation because no or few germination occurs at 60\% RH (Beyer et al. 2005; Sung and Cook 1981). Temperature and RH inside incubators were monitored for the duration of the experiments using data loggers (Tinytag Plus 2 TGP-4500, Gemini Data Loggers, Chichester, UK). No condensation was observed on slides or in Petri dishes for the duration of the experiment. At the end of each DP, the blotting paper was wetted with $1.5 \mathrm{ml}$ of sterile-deionized water, and dishes were sealed with Parafilm (Neenah, WI) to obtain a saturated atmosphere (100\% RH). These dishes were then incubated at $20^{\circ} \mathrm{C}$ for $24 \mathrm{~h}$ before germination was assessed as described earlier. The percentage of germinated ascospores was recorded as a measure of ascospore viability.

Effect of RH. For assessment of RH effects on ascospore germination, microscope slides were prepared as described earlier (three drops of ascospore suspension per slide, two slides per fungal strain). Once the drops had dried, the slides were placed on a metal grid in plastic boxes $(19 \times 13 \times 4 \mathrm{~cm})$ and incubated at $20^{\circ} \mathrm{C}$ and with $32.5,65.5,76.0,93.5$, or $100 \% \mathrm{RH}$ for $24 \mathrm{~h}$ before germination was assessed as described earlier. Different $\mathrm{RH}$ levels were obtained by placing saturated aqueous salt solutions $\left(\mathrm{CaCl}_{2}, \mathrm{NH}_{4} \mathrm{NO}_{3}, \mathrm{NaCl}\right.$, and $\mathrm{KNO}_{3}$ for $32.5,65.5,76.0$, and $93.5 \% \mathrm{RH}$, respectively; Dhingra and Sinclair 1995) or distilled water (for 100\% RH) in the boxes. The boxes were sealed in transparent plastic bags, and the real value of RH inside the boxes was measured with data loggers (Tinytag Plus 2 TGP-4500, Gemini Data Loggers) for the duration of the experiment. Boxes with the different RH levels were arranged in the incubator according to a complete randomized design.

To study the effects of RH on ascospore germination during DP of varying lengths, an experiment was set up as described earlier and microscope slides were incubated for $0,3,6,12$, or $24 \mathrm{~h}$ (boxes to be assessed at these different times were arranged in the incubator according to a complete randomized design). At the end of each DP, 
microscope slides were transferred to another box in which salt solutions were replaced with distilled water to obtain $100 \% \mathrm{RH}$. After $24 \mathrm{~h}$ at $100 \% \mathrm{RH}$, ascospore germination was assessed as described earlier.

In planta experiments. Durum wheat plants (cultivar Saragolla, which is susceptible to FHB) were grown in pots $(14 \times 14 \times$ $20 \mathrm{~cm}^{3}$ ) in a greenhouse; there were 10 spikes per pot at heading. On 20 May 2013 and 9 May 2014, when plants were at full anthesis (stage 65 of the BBCH scale, Meier 2001), spikes were inoculated with an ascospore suspension $\left(2 \times 10^{4}\right.$ ascospores $/ \mathrm{ml}$, Rossi et al. 2007) of the two fungal strains, prepared as described earlier; $1 \mathrm{ml}$ of ascospore suspension was nebulized per spike. After inoculation, plants were subjected to DP that lasted for $0,6,12,24$, or $48 \mathrm{~h}$; air temperature during the DP was $15.2 \pm 2^{\circ} \mathrm{C}$ in 2013 and $15.5 \pm$ $2{ }^{\circ} \mathrm{C}$ in 2014; RH was $65.5 \pm 5 \%$ in 2013 and $65.1 \pm 5 \%$ in 2014 (these $\mathrm{RH}$ levels were considered similar to dry conditions tested in the laboratory experiments). For the uninoculated control, spikes were nebulized with sterile distilled water instead of an ascospore suspension. Pots were assigned to the different DP and to the uninoculated control (treatments) according to a randomized block design, with four replicate pots per treatment (10 spikes per pot).

At the end of each DP, plants were sealed in a transparent plastic bag for $48 \mathrm{~h}$. To guarantee high humidity, the internal side of the plastic bags was sprayed with water. After $48 \mathrm{~h}$ at near $100 \% \mathrm{RH}$, the plastic bags were removed, and plants were kept outdoors. In 2013, average temperature for the whole period outdoors was $19.5^{\circ} \mathrm{C}$, with a total of $66 \mathrm{~h}$ with $\mathrm{RH} \geq 90 \%$, and $78.8 \mathrm{~mm}$ of rain in 6 rainy days. In 2014, average temperature was 16.2 , with a total of $179 \mathrm{~h}$ with $\mathrm{RH} \geq 90 \%$, and $91.8 \mathrm{~mm}$ of rain in 6 rainy days. Symptoms first appeared 7 to 9 days after infection.

Spike samples (five spikes per sample) were collected 3 and 9 days after the plants had been sealed in plastic bags and at maturity on 24 June 2013 and on 22 June 2014. Spikes were carefully washed under tap water, brushed to remove epiphytical mycelia, and washed again under tap water for $30 \mathrm{~min}$. Spikes were then dried with blotting paper, frozen in liquid nitrogen, and stored at $-80^{\circ} \mathrm{C}$ until they were processed for DNA content.

In 2014, FHB index was calculated assessing 20 random spikes per DP (five spikes for each replicate pot per treatment) at 20 days postinfection (dpi). FHB severity was assessed on individual spikes as the percentage of spikelets with bleaching per spike, sometimes with pink/orange mycelia at the edge of the glumes. FHB index was then calculated per each replicate pot as average disease severity.

Fusarium DNA analysis. F. graminearum mycelium was grown and lyophilized as described by Terzi et al. (2007). DNA was extracted from the lyophilized mycelium as described by AlSamarrai and Schmid (2000). A 10-fold dilution series of the DNA was used to prepare a standard curve for $F$. graminearum DNA as described in the next section.

DNA extraction from wheat samples. After spike tissue was finely ground in liquid nitrogen and with a mortar and pestle, DNA was extracted according to Terzi et al. (2007). The primer pair 22F (AATATGGAAAACGGAGTTCATCTACA)/122R (ATTGCC GGTGCCTGAAAGT), designed from the Tri5-Tri6 intergenic sequence (AY134892 accession number), was used for the real-time quantitative polymerase chain reaction (qPCR) analysis of the samples (Terzi et al. 2007). qPCR was carried out in a $20-\mu l$ reaction volume containing $10 \mu \mathrm{l}$ of KAPA SYBR FAST ABI Prism qPCR kit (Kapa Biosystems, Wilmington, MA), $0.4 \mu$ l of both the F and the R primer $(10 \mu \mathrm{M}), 2 \mu \mathrm{l}$ of template DNA solution $(10 \mathrm{ng} / \mu \mathrm{l})$, and $7.2 \mu \mathrm{l}$ of water. The amplification was conducted with a 7300 Real-time PCR System (Applied Biosystems, Foster City, CA) and with the following cycling protocol: $95^{\circ} \mathrm{C}$ for $3 \mathrm{~min}$ and 40 cycles of $95^{\circ} \mathrm{C}$ for $3 \mathrm{~s}$ and $60^{\circ} \mathrm{C}$ for $30 \mathrm{~s}$. A melting curve analysis step $\left(95^{\circ} \mathrm{C}\right.$ for $15 \mathrm{~s}, 60^{\circ} \mathrm{C}$ for $30 \mathrm{~s}$, and $95^{\circ} \mathrm{C}$ for $15 \mathrm{~s}$ ) was included in each run to confirm the amplification of a single gene product and to control for false-positive results caused by primer-dimer hybridization and nonspecific amplifications. For the quantification of Fusarium
DNA, a standard curve was generated by using the 10 -fold dilution series of pure $F$. graminearum DNA that was described in the previous section; for this standard curve, cycle threshold $(\mathrm{Ct})$ values of the diluted DNA were plotted against the $\log _{10}$ amount of DNA. The quantity of fungal DNA in the wheat samples was estimated based on the comparison with the standard curve (which was run in parallel reactions), and the results were expressed as picogram of fungal DNA per nanogram of total DNA (of plant and fungal origin) extracted from a sample.

As reported by Terzi et al. (2007), the lower detection limit of the assay was 4 pg of fungal DNA, corresponding to about 100 $F$. graminearum haploid genomes. The specificity of the assay was previously evaluated on a panel of different Fusarium species (Terzi et al. 2007).

Data analysis. The effects of DP duration, temperature, and RH on ascospore viability in the in vitro experiments were assessed with a factorial analysis of variance (ANOVA) for a complete randomized design, with four main factors: DP duration and temperature or RH were considered fixed factors while replicate run and fungal strain were considered random factors, with three and two levels, respectively. Before analysis, percentages were arcsinetransformed to make variances homogeneous.

Regression analysis was used to study how ascospore germination was affected by DP duration $\times$ temperature and DP duration $\times \mathrm{RH}$. The data were rescaled by dividing the percentage of germinated ascospores at any combination of DP $\times$ temperature or $\mathrm{DP} \times \mathrm{RH}$, depending on the experiment, by the percentage obtained with no exposure to dryness (DP $=0 \mathrm{~h}$ ). Different linear and nonlinear regression models were compared based on the Akaike's information criterion (AIC), and the model with the lowest AIC value was selected as the best (Burnham and Anderson 2002).

The effects of DP duration on the $F$. graminearum DNA content in the in planta experiments were assessed with ANOVA for a factorial randomized block design, with two main, fixed factors: DP duration and year. ANOVA was performed for data at $3 \mathrm{dpi}, 9 \mathrm{dpi}$, and maturity separately. The effects of DP duration on the FHB index in 2014 were assessed by a one-way ANOVA for a randomized block design. Before analyses, picogram of fungal DNA per nanogram of total DNA were transformed using the natural logarithm function and FHB index values were arcsine-transformed to make variances homogeneous.

SPSS (SPSS ver. 21, IBM SPSS Statistics, IBM Corp., New York) was used for all statistical analyses.

\section{RESULTS}

Ascospore germination as affected by temperature and RH but without prior exposure to dryness. At $100 \% \mathrm{RH}$, irrespective of the fungal strain, no ascospores germinated after $24 \mathrm{~h}$ of incubation at either 5 or $40^{\circ} \mathrm{C}$, germination reached the maximum at 20 and $25^{\circ} \mathrm{C}$ (Fig. $1 \mathrm{~A}$ ). At $20^{\circ} \mathrm{C}$ and $100 \% \mathrm{RH}$, almost all ascospores had germinated by $12 \mathrm{~h}$ (Fig. 1B). When ascospores were kept at $20^{\circ} \mathrm{C}$ with $32.5,65.5,76.0$, or $93.5 \% \mathrm{RH}$ for $24 \mathrm{~h}$, germination ranged from 3 to $5 \%$ (data not shown).

Ascospore germination after exposure to dryness. In all treatments some ascospores remained viable, i.e., in all combinations of DP $\times$ temperature and $\mathrm{DP} \times \mathrm{RH}$. When ascospores were not exposed to dryness ( $D P=0 \mathrm{~h}$ ), $86.5 \pm 1.9 \%$ germinated (average of the three experiments and of the two fungal strains). DP duration $(P<0.001)$ and the interaction DP $\times$ temperature during the DP $(P<$ 0.001 ) significantly affected ascospore viability (measured as germinated ascospores) and globally accounted for approximately $60 \%$ of the total variance of the experiment. The percentage of ascospores that germinated declined as the DP duration increased, and the reduction in germination increased as temperature increased during the DP (Fig. 2A). After a 48-h DP, germination was reduced by $<50 \%$ at 5 and $10^{\circ} \mathrm{C}$ compared with ascospores not exposed to dryness, by 59.5 and $68.2 \%$ at 15 to $30^{\circ} \mathrm{C}$, respectively, and by $>90 \%$ at 35 and $40^{\circ} \mathrm{C}$, respectively (Fig. 2A). 
Irrespective of temperature $(P=0.721$ for the interaction of strain $\times$ temperature $\times \mathrm{DP})$, the German strain was less sensitive to dryness than the Italian one $(P=0.013$ for interaction strain $\times D P)$. When ascospores were not exposed to dryness, germination for the two strains was similar (87.4 and $85.6 \%$, respectively) (Fig. 2B). For ascospores exposed to DP of any duration $(>0 \mathrm{~h})$, germination was higher for the German strain than for the Italian strain; after $48 \mathrm{~h}$ of dryness, germination was $38.4 \%$ for the German strain and $22.0 \%$ for the Italian strain (Fig. 2B).

Equation 1 provides a good fit to the rescaled data for ascospore germination as a function of DP duration and temperature during the DP:
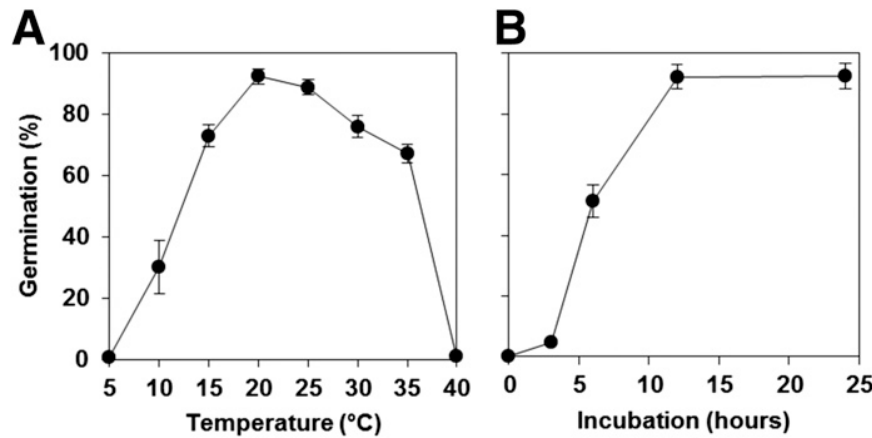

Fig. 1. Effect of $\mathbf{A}$, temperature and $\mathbf{B}$, incubation time on germination of Fusarium graminearum ascospores incubated at $100 \%$ relative humidity $(\mathrm{RH})$ and without a prior dry period. For quantification of germination, drops $(20 \mu \mathrm{l}$ each) of an ascospore suspension $\left(2 \times 10^{4}\right.$ ascospores $\left./ \mathrm{ml}\right)$ were placed on microscope slides, briefly dried in a laminar flow hood, and then incubated with $100 \% \mathrm{RH}$ and at different temperatures for $24 \mathrm{~h}(\mathbf{A})$ or at $20^{\circ} \mathrm{C}$ for different times $(\mathbf{B})$. The percentage of germination was assessed by examining 100 random ascospores per drop. Dots are means and error bars are standard errors of 36 measurements (three experiments, two fungal strains, and six replicate drops).

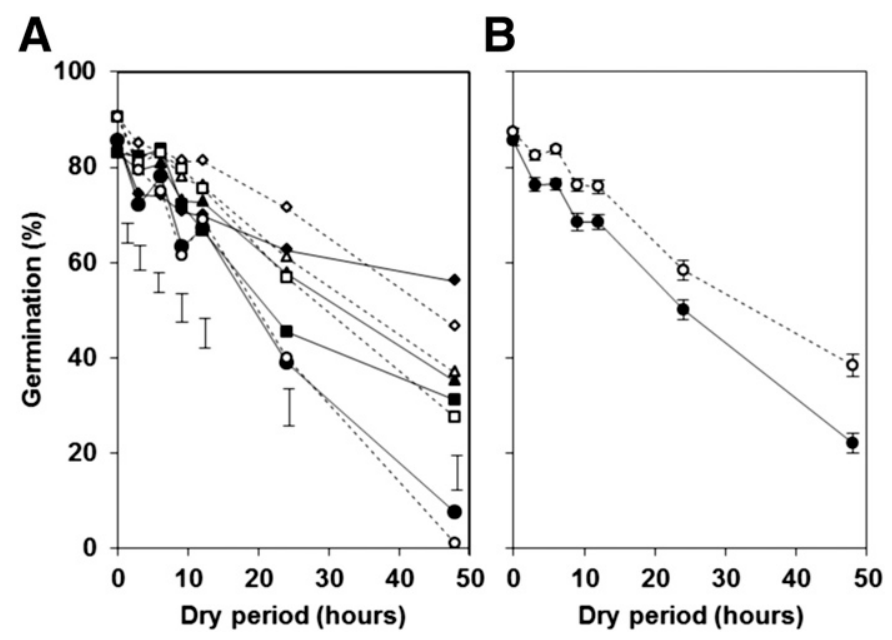

Fig. 2. Effect of dry periods (DP) on germination of Fusarium graminearum ascospores. A, Dots represent different temperature regimes during the DP: $\bullet=5, \diamond=10, \boldsymbol{\Delta}=15, \Delta=20, \boldsymbol{\square}=25, \square=30, \boldsymbol{\bullet}=35$, and $\bigcirc=40^{\circ} \mathrm{C}$. B, Dots represent one fungal strain originating from Italy ( IT) and one from Germany $(\bigcirc \mathrm{DE})$. For quantification of germination, drops $(20 \mu \mathrm{l}$ each) of an ascospore suspension $\left(2 \times 10^{4}\right.$ ascospores $\left./ \mathrm{ml}\right)$ were placed on microscope slides, briefly dried in a laminar flow hood, and then incubated at $60 \%$ relative humidity at different temperatures and for different times. At the end of each incubation period, ascospores were transferred to a saturated atmosphere at $20^{\circ} \mathrm{C}$ for $24 \mathrm{~h}$ before the percentage of germination was assessed based on examination of 100 random ascospores per drop. A, Dots are means of 36 measurements (three experiments, two fungal strains, and six replicate drops) and error bars are the standard errors averaged over each DP duration. B, Dots are means and error bars are standard errors of 144 measurements (three experiments, six replicate drops, and eight temperatures).

$$
Y=a+b \times \mathrm{DP}+c \times \mathrm{DP} \times \text { temp }^{2}
$$

where $Y$ is the rescaled ascospore germination (i.e., ascospore viability; 0 to 1 ); DP is the duration of the dry period (in hours); temperature is the temperature during the $\mathrm{DP}\left({ }^{\circ} \mathrm{C}\right)$; and $a, b$, and $c$ are equation parameters: $a=0.98 \pm 0.01, b=-0.009 \pm 0.001$, and $c=-7.73 \times 10^{-6} \pm 0.90 \times 10^{-6}$. This equation accounted for the curvilinear decrease of ascospore germination over time when ascospores were kept in a dry atmosphere and at increasing temperature (Fig. 3A). Standard errors of equation parameter estimates were low, and the $R^{2}$ was 0.95 . A plot of observed versus predicted values did not show systematic deviations (Fig. 3B), and the regression line between the two series of data had an intercept $(a)$ of 0.02 and a slope $(b)$ of 0.97 , which were not significantly different from $0(P=0.345)$ and $1(P=0.122)$, respectively.

DP duration and RH during the DP significantly affected $(P=$ 0.022 and 0.015 , respectively) ascospore viability, but the interaction DP $\times \mathrm{RH}$ did not $(P=0.454)$. Neither experiment nor fungal strain significantly affected viability $(P=0.073$ and 0.323 , respectively). Germination decreased as DP duration increased (Fig. 4). Germination of the ascospores not exposed to dryness was $81.5 \pm 2.9 \%$; irrespective of DP duration, germination was lower for ascospores kept at $65.5 \% \mathrm{RH}$ than at 76.0 or $32.5 \% \mathrm{RH}$, and at $93.5 \% \mathrm{RH}$. For instance, at DP $=6 \mathrm{~h}$, germination was reduced by $63.4,48.6,46.0$, and $30.9 \%$ at $65.5,76.0,32.5$, and $93.5 \% \mathrm{RH}$, respectively, compared with the ascospores not exposed to dryness (Fig. 4).

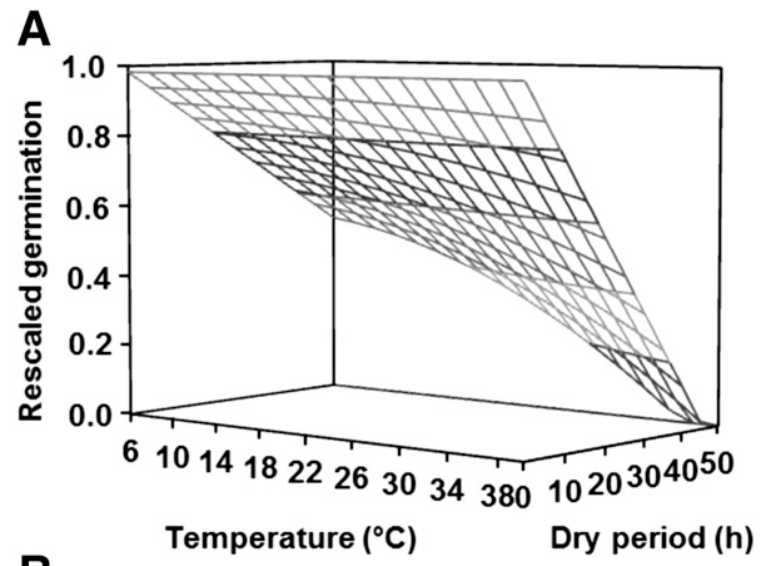

B

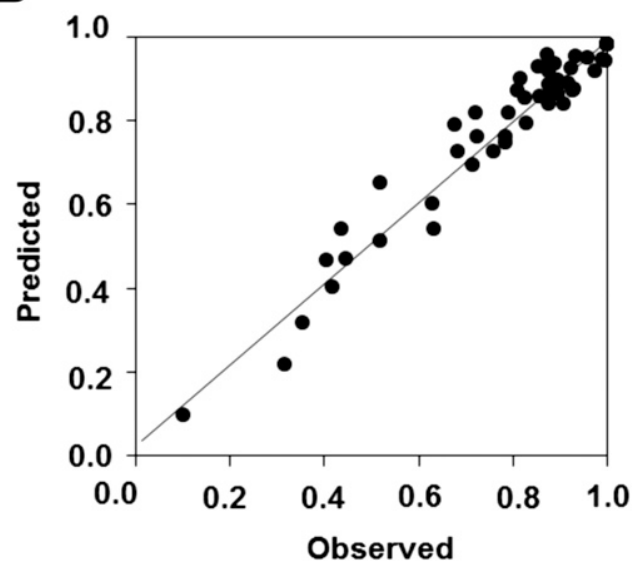

Fig. 3. A, Fit of the effect of dry period (DP) duration and temperature during the DP on relative germination of Fusarium graminearum ascospores using equation 1 (see text), and $\mathbf{B}$, plot of predicted versus observed data. $\mathbf{B}$, The line is the linear regression between the two series of data, with $a=0.02, b=0.97$, and $R^{2}=0.95$. Rescaled germination was calculated by dividing germination of the ascospores exposed to dryness by germination of ascospores that were not exposed to dryness. 
Equation 2 provides a good fit to the rescaled data for ascospore germination as a function of DP duration and RH during the DP:

$$
\begin{aligned}
Y= & \left(a+b \times \mathrm{RH}+c \times \mathrm{RH}^{2}+d \times \mathrm{RH}^{3}\right) \\
& -\left(e+f \times \mathrm{RH}+g \times \mathrm{RH}^{2}\right) \times \ln (\mathrm{DP})
\end{aligned}
$$

where $Y$ is the rescaled ascospore germination (i.e., ascospore viability; 0 to 1); DP is the duration of the dry period (in hours); RH is the RH during the DP (\%); $a$ to $g$ are equation parameters: $a=3.29 \pm$ $1.01, b=-0.126 \pm 0.055, c=0.002 \pm 0.001, d=-9.85 \times 10^{-6} \pm$ $0.80 \times 10^{-6}, e=-0.038 \pm 0.107, f=0.009 \pm 0.004$, and $g=$ $-7.84 \times 10^{-5} \pm 0.90 \times 10^{-5}$. This equation accounted for the decrease in ascospore germination during a DP and the curvilinear effect of RH during such a DP (Fig. 5A). Standard errors of equation parameter estimates were low, and the $R^{2}$ was 0.95 . A plot of observed versus predicted values did not show systematic deviations (Fig. 5B), and the regression line between the two series of data had an intercept $(a)$ of 0.04 and a slope $(b)$ of 0.95 , which were not significantly different from $0(P=0.343)$ and $1(P=0.148)$, respectively.

Spike infection after exposure to dryness. The qPCR reaction generated satisfactory standard curve when $\mathrm{Ct}$ values were plotted on the $\log _{10}$ amount of pure DNA of $F$. graminearum in a 10fold dilution series. The slope of the standard curve (from the most concentrated to the least concentrated sample) was -3.3 in 2013 and -3.6 in 2014, both in the optimal range, and the values obtained from three replicates had a high uniformity. The melting curve showed a single peak, indicating that primer dimers were absent and that other targets had not been amplified.

Results for fungal biomass at 3 dpi were different in 2013 versus 2014 (the interaction between dpi $\times$ year was significant: $P<0.001$ ). At 3 dpi in 2013, $F$. graminearum DNA was detected only in spikes not exposed to dryness (Fig. 6, left). At 3 dpi in 2014, F. graminearum DNA was detected regardless of DP duration but the quantity detected tended to decrease as DP duration increased (Fig. 6, right).

At 9 dpi, fungal biomass was affected by DP duration $(P=0.019)$, irrespective of the year $(P=0.870$ for the interaction dpi $\times$ year $)$. In both years, the fungal DNA content did not significantly differ with DP of 0,6 , and $12 \mathrm{~h}$ but was lower with DP of 24 and $48 \mathrm{~h}$ than with shorter DP (Fig. 6).

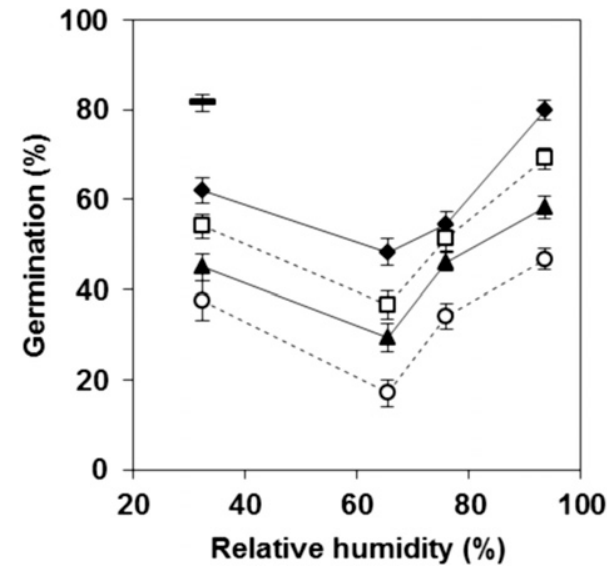

Fig. 4. Effect of dry period (DP) duration and relative humidity during the DP on germination of Fusarium graminearum ascospores. Dots represent length of DP: $\downarrow=3, \square=6, \boldsymbol{\Delta}=12$, and $\bigcirc=24 \mathrm{~h}$; the symbol - represents germination of ascospores not exposed to dryness. For quantification of germination, drops $\left(20 \mu \mathrm{l}\right.$ each) of an ascospore suspension $\left(2 \times 10^{4}\right.$ ascospores $\left./ \mathrm{ml}\right)$ were placed on microscope slides, briefly dried in a laminar flow hood, and then incubated at different humidity levels and for different times at $20^{\circ} \mathrm{C}$. At the end of each incubation period, ascospores were transferred to a saturated atmosphere at $20^{\circ} \mathrm{C}$ for $24 \mathrm{~h}$, and the percentage of germination was assessed based on examination of 100 random ascospores per drop. Dots are means and error bars are standard errors of 36 values (three experiments, two fungal strains, and six replicate drops).
At harvest (35 dpi in 2013 and 43 dpi in 2014), fungal biomass was greater than at 3 and 9 dpi but was not affected by year $(P=$ $0.184)$ or DP duration after inoculation $(P=0.654)$; the overall average for $F$. graminearum DNA content at harvest was $268.8 \pm$ $37.6 \mathrm{pg} / \mathrm{ng}$ of total DNA (Fig. 6).

At 20 dpi in 2014, FHB index was $32.9 \pm 7.5,22.3 \pm 5.3,27.9 \pm$ $3.5,23.6 \pm 7.4$, and $17.5 \pm 5.7$ for spikes exposed to $0,6,12,24$, or
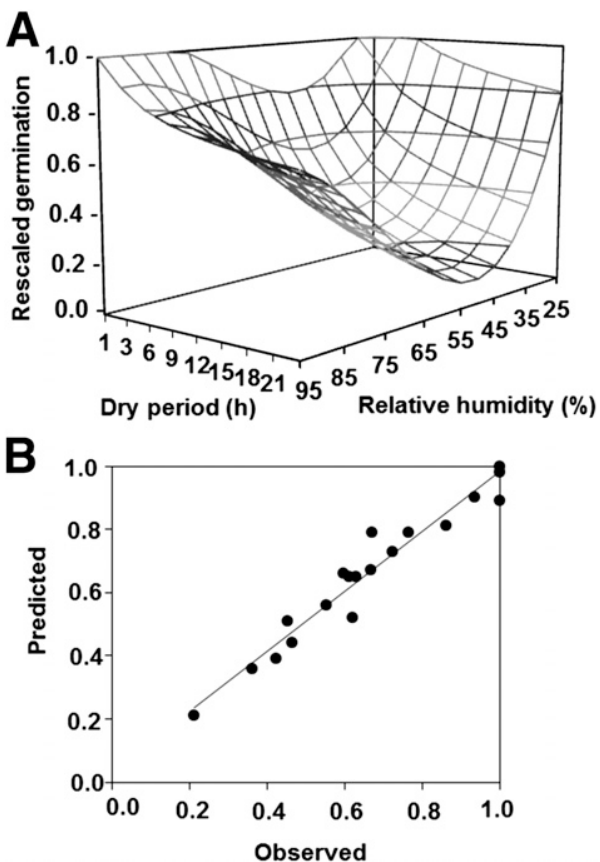

Fig. 5. A, Fit of the effect of dry periods (DP) and relative humidity during the DP on relative germination of Fusarium graminearum ascospores using equation 2 (see text), and $\mathbf{B}$, plot of predicted versus observed data. $\mathbf{B}$, The line is the linear regression between the two series of data, with $a=0.04, b=0.95$, and $R^{2}=0.95$. Rescaled germination was calculated by dividing germination of the ascospores exposed to dryness by germination of ascospores that were not exposed to dryness.

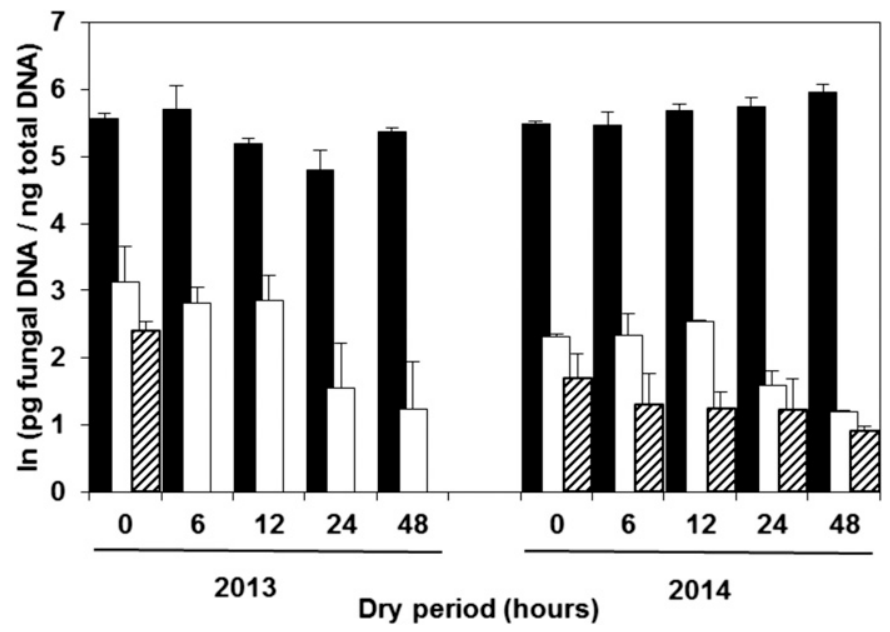

Fig. 6. Biomass of Fusarium graminearum (expressed as the natural logarithm of picogram [pg] of fungal DNA/nanogram [ng] of total DNA) in durum wheat spikes inoculated with ascospores and then exposed to dry periods (DP) for 0 to $48 \mathrm{~h}$. Spikes were inoculated ( $1 \mathrm{ml}$ of ascospore suspension of the two fungal strains, $2 \times 10^{4}$ ascospores $/ \mathrm{ml}$ ) at full anthesis and kept outdoors (but protected from rain) at $15^{\circ} \mathrm{C}$ and $65 \%$ relative humidity (RH) for 0 to $48 \mathrm{~h}$ (the DP). At the end of each DP, plants were sealed in a transparent plastic for $48 \mathrm{~h}$ at $100 \%$ RH to allow infection. Dots are means and error bars standard errors of 4 replicated samples ( 20 spikes per sample) at 3 days after infection (lined bars), 9 days after infection (white bars), and at maturity (black bars). 
$48 \mathrm{~h}$ of dryness, respectively, after ascospore inoculation. These differences were not significant $(P=0.448)$.

\section{DISCUSSION}

In this paper, most of the $F$. graminearum ascospores discharged from mature perithecia of the two fungal isolates germinated within $12 \mathrm{~h}$ at $100 \% \mathrm{RH}$ and $20^{\circ} \mathrm{C}$, but only few germinated within a 24-h period at lower RH levels (between 93.5 and 32.5\%). Beyer et al. (2005) and Beyer and Verreet (2005) also reported that a high percentage of ascospore germination occurred only with a very high $\mathrm{RH}$, even though the germination percentages at $\mathrm{RH}>70 \%$ were higher in these earlier studies than in our experiments. Ascospores were supported by microscope slides in our study and by $1.5 \%$ water agar in the two other studies, i.e., the ascospores may have had access to more water in the two other studies than in our study.

This paper has provided new information about the viability of $F$. graminearum ascospores after exposure to a DP and on the effect of temperature and RH during that DP. None of the tested combinations of DP duration, temperature, and $\mathrm{RH}$ resulted in the death of all ascospores. In other words, viable ascospores were found at all temperatures, relative humidities, and DP tested, confirming that some $F$. graminearum ascospores are able to remain viable under conditions that are unfavorable for germination (Beyer and Verreet 2005; Francl 1998; Gilbert et al. 2008; Jin et al. 2001; Schmale and Bergstrom 2004; Schmale et al. 2006). Nevertheless, the proportion of viable ascospores sharply decreased with an increase in the duration of the DP, and the rates of decrease depended on temperature and RH. As previously observed by Gilbert et al. (2008) for a narrower temperature interval (15, 20, and $30^{\circ} \mathrm{C}$ ), viability decreased with increasing temperature, and the decrease was the highest at 35 and $40^{\circ} \mathrm{C}$ in the current study. Consistent with Gilbert et al. (2008), viability was lower at $65.5 \%$ $\mathrm{RH}$ than at either higher or lower RH levels, with germination dropping from $82 \%$ at $100 \%$ RH to $17 \%$ after a 24 -h exposure at $65.5 \% \mathrm{RH}$ at $20^{\circ} \mathrm{C}$. Similar response to $\mathrm{RH}$ was also found in other fungi (Akusie and Clerk 1981; Leong et al. 2006; Nicholson and Moraes 1980; Tisserat and Kuntz 1983).

Beyer and Verreet (2005) found that incubation of ascospores at $53 \% \mathrm{RH}\left(20^{\circ} \mathrm{C}\right)$ decreased the percentage of viable spores from 93 to $6 \%$ within $10 \mathrm{~min}$. Such a low viability of ascospores in the study of Beyer and Verreet (2005) is difficult to explain based on the results in Gilbert et al. (2008) and in the current study. Given that the ascospores of the two $F$. graminearum strains used in this study differed somewhat in survival ability, the discrepancy in ascospore survival among studies may be due to the difference among the $F$. graminearum isolates. The effect of $F$. graminearum isolates on ascospore survival should be further investigated. Genetic variability of $F$. graminearum has been reported (Leslie and Summerell 2006), but few and contradicting studies were conducted on the effect of this variability on fungal response to temperature (Brennan et al. 2003; Cook and Christen 1976; Ramirez et al. 2006; Rossi et al. 2001, 2002) or water activity (Jiménez et al. 1996).

Beyer and Verreet (2005) reported that viable ascospores are swollen (both before and during the formation of germ tubes) and internally homogeneous, and that nonviable spores are not swollen and are internally granular. These authors concluded that viable and nonviable ascospore cells can be easily distinguished by light microscopy. We also found that internally granular ascospores failed to germinate, but we also found swollen and internally homogeneous ascospores that failed to form germ tubes even after $\geq 24 \mathrm{~h}$ under optimal conditions.

To our knowledge, this is the first published report concerning the effect of ascospore viability on infection severity of wheat plants. Infection severity after ascospore-inoculated spikes were exposed to dry conditions was evaluated by quantifying (via qPCR) the fungal biomass in the spike tissue as picograms of $F$. graminearum DNA per nanograms of total DNA. qPCR has been extensively used to detect, identify, and quantify $F$. graminearum (reviewed in Morcia et al. 2013) and to study the genes involved in mycotoxin synthesis (Doohan et al. 1999; Lysøe et al. 2009; Marín et al. 2010; Yoruk and Albayrak 2014). Correlation between qPCR results and FHB severity and/or mycotoxin contamination has been frequently reported (Burlakoti et al. 2007; Demeke et al. 2010; Horevaj et al. 2011; Rossi et al. 2007; Schnerr et al. 2001; Terzi et al. 2007; Zhang et al. 2009).

Consistent with the effects of DP on in vitro ascospore viability, exposure of wheat spikes inoculated with ascospores to DP before infection reduced fungal biomass at both 3 and 9 days after inoculation. This reduction in fungal biomass in the early stages of spike invasion did not result in differences in the ultimate disease level, as demonstrated by FHB index and fungal biomass. This result was not unexpected. Wheat spikes were inoculated at full flowering with a high inoculum dose $\left(2 \times 10^{4}\right.$ ascospores per spike), and although exposure to DP reduced ascospore viability and thus the initial infection severity, this did not reduce fungal spread within the spike tissue during kernel ripening. Severe FHB is due to the infection of several spikelets and to the spread of the fungus through the rachis (Bai et al. 2002; Brown et al. 2010; Del Ponte et al. 2007; Francl et al. 1999; Schaafsma et al. 2005).

The relationship between inoculum density and disease observed by Stack (1989) and Stein et al. (2009) may explain the lack of differences in disease severity at kernel maturity in our experiments. In one inoculation experiment with 1, 10,100, and 1,000 ascospores per wheat spike, Stack (1989) found approximately 5, 10, 20, and $70 \%$ disease severity; in another experiment, grain yield per spike was approximately $2.0,1.3,1.1$, and $0.4 \mathrm{~g}$ at the four inoculum doses, respectively, with a grain yield of $2.1 \mathrm{~g}$ in the uninoculated spikes. Therefore, each additional ascospore in the inoculum accounted for $5.0,0.5,0.15$, and $0.055 \%$ severity, and $0.1,0.08$, 0.01 , and $0.0017 \mathrm{~g}$ of yield loss at the four inoculum doses, respectively. It follows that the loss of ascospores at high inoculum doses (as in this work) may have little or no effect on the final disease. Based on the results of Stein et al. (2009); Fig. 1B in that study), reducing the final disease severity in our experiments would have required that our inoculum dose be reduced by approximately $75 \%$ (from $2 \times 10^{4}$ to $5 \times 10^{3}$ spores per spike). Such a reduction in inoculum dose, however, would have probably caused fungal biomass to be undetectable a few days after inoculation, and detecting differences in fungal biomass a few days after inoculation was an important objective in this work.

In the field, loss of ascospores due to reduced viability during DP may have a different effect on the final disease than in the conditions of this study because fewer ascospores are deposited on spikes in the field than in artificial inoculations. Panisson et al. (2002) trapped from 0.66 to 1.35 ascospores $/ \mathrm{cm}^{2}$ of trapping surface per day during wheat anthesis in Brazil. Manstretta et al. (2015) trapped an average of 2.67 ascospores $/ \mathrm{cm}^{2}$ per day in passive spore traps that were placed in the wheat canopy to mimic wheat spikes. Paul et al. (2007) found that the mean daily number of propagules of $F$. graminearum (both ascospores and conidia) recovered from wheat spikes, quantified as colony forming units (CFUs) per spike, varied among locations and among years at one location. For any given location and year, there was substantial day-to-day variation ranging from 0 to $>5,000$ CFUs per spike. Francl et al. (1999) observed multiple inoculation events consisting of $\geq 50 \mathrm{CFUs}$ of $F$. graminearum per spike per day in areas with moderate and severe epidemics, and low average inoculum levels and isolated cases of deposition $>50$ CFUs in nonepidemic areas.

Overall, our results indicate that DP reduces the viability of the $F$. graminearum ascospores and the biomass of the fungus in the wheat spikes after infection. However, a percentage of the ascospores remain viable for an extended period and may serve as a source of inoculum for infecting hosts. This percentage depends upon length of the DP and on the temperature and RH during that period. Equations were developed that describe these relationships 
and that estimate the proportion of ascospores that lose the ability to germinate when they experience unfavorable conditions after discharge from perithecia and when deposited on the wheat head. This information can be integrated in predictive models that consider the relative quantity of inoculum, such as the Brazilian model GIBSIM (Del Ponte et al. 2005) or the prototype model for $F$. graminearum ascospore risk of Gourdain and Rossi (2011).

\section{ACKNOWLEDGMENTS}

We thank M. Herrmann for providing the German fungal strain. This study was supported by the Doctoral School on the Agro-Food System (Agrisystem) of the Università Cattolica del Sacro Cuore (Italy) and by SO.FI.A. MIUR project.

\section{LITERATURE CITED}

Akusie, P. L., and Clerk, G. C. 1981. Effect of relative humidity on viability of Rhizopus oryzae sporangiospores. Trans. Br. Mycol. Soc. 76:322-334.

Al-Samarrai, T. H., and Schmid, J. 2000. A simple method for extraction of fungal genomic DNA. Lett. Appl. Microbiol. 30:53-56.

Bai, G. H., Desjardins, A. E., and Plattner, R. D. 2002. Deoxynivalenolnonproducing Fusarium graminearum causes initial infection, but does not cause disease spread in wheat spikes. Mycopathologia 153:91-98.

Beyer, M., and Verreet, J.-A. 2005. Germination of Gibberella zeae ascospores as affected by age of spores after discharge and environmental factors. Eur. J. Plant Pathol. 111:381-389.

Beyer, M., Verreet, J.-A., and Ragab, W. S. M. 2005. Effect of relative humidity on germination of ascospores and macroconidia of Gibberella zeae and deoxynivalenol production. Int. J. Food Microbiol. 98:233-240.

Brennan, J. M., Fagan, B., Van Maanen, A., Cooke, B. M., and Doohan, F. M. 2003. Studies on in vitro growth and pathogenicity of European Fusarium fungi. Eur. J. Plant Pathol. 109:577-587.

Brown, N. A., Urban, M., van de Meene, A. M. L., and Hammond-Kosack, K. E. 2010. The infection biology of Fusarium graminearum: Defining the pathways of spikelet to spikelet colonisation in wheat ears. Fungal Biol. 114:555-571.

Burlakoti, R. R., Estrada, R., Rivera, V. V., Boddeda, A., Secor, G. A., and Adhikari, T. B. 2007. Real-time PCR quantification and mycotoxin production of Fusarium graminearum in wheat inoculated with isolates collected from potato, sugar beet, and wheat. Phytopathology 97:835-841.

Burnham, K. P., and Anderson, D. R. 2002. Model Selection and Multimodel Inference. A Practical Information-Theoretic Approach. Springer-Verlag, New York

Cook, R. J., and Christen, A. A. 1976. Growth of cereal root-rot fungi as affected by temperature-water potential interactions. Phytopathology 66:193-197.

de Luna, L., Bujold, I., Carisse, O., and Paulitz, T. C. 2002. Ascospore gradients of Gibberella zeae from overwintered inoculum in wheat fields. Can. J. Plant Pathol. 24:457-464.

Del Ponte, E. M., Fernandes, J. M. C., and Bergstrom, G. C. 2007. Influence of growth stage on Fusarium head blight and deoxynivalenol production in wheat. J. Phytopathol. 155:577-581.

Del Ponte, E. M., Fernandes, J. M. C., and Pavan, W. 2005. A risk infection simulation model for Fusarium head blight of wheat. Fitopatol. Bras. 30: 634-642.

Del Ponte, E. M., Shah, D. A., and Bergstrom, G. C. 2003. Spatial patterns of Fusarium head blight in New York wheat fields suggest role of airborne inoculum. Published Online. Plant Health Progress. doi:10.1094/PHP-20030418-01-RS

Demeke, T., Gräfenhan, T., Clear, R. M., Phan, A., Ratnayaka, I., Chapados, J., Patrick, S. K., Gaba, D., Lévesque, C. A., and Seifert, K. A. 2010. Development of a specific TaqMan real-time PCR assay for quantification of Fusarium graminearum clade 7 and comparison of fungal biomass determined by PCR with deoxynivalenol content in wheat and barley. Int. J. Food Microbiol. 141:45-50.

Dhingra, O. D., and Sinclair, J. B. 1995.Pages 319-325 in: Basic Plant Pathology Methods. CRC Press, Boca Raton, FL.

Doohan, F. M., Parry, D. W., and Nicholson, P. 1999. Fusarium ear blight of wheat: The use of quantitative PCR and visual disease assessment in studies of disease control. Plant Pathol. 48:209-217.

Fernando, W. G., Paulitz, T. C., Seaman, W. L., Dutilleul, P., and Miller, J. D. 1997. Head blight gradients caused by Gibberella zeae from area sources of inoculum in wheat field plots. Phytopathology 87:414-421.

Fernando, W. G. D., Miller, J. D., Seaman, W. L., Seifert, K., and Paulitz, T. C. 2000. Daily and seasonal dynamics of airborne spores of Fusarium graminearum and other Fusarium species sampled over wheat plots. Can. J. Bot. 78:497-505.
Francl, L., Shaner, G., Bergstrom, G. C., Gilbert, J., Pedersen, W., Dill-Macky, R., Sweets, L., Corwin, B., Jin, Y., Gallenberg, D., and Wiersma, J. 1999. Daily inoculum levels of Gibberella zeae on wheat spikes. Plant Dis. 83:662-666.

Francl, L. J. 1998. Development of Fusarium head blight in relation to environment and inoculum. Pages 1-3 in: Proc. 1998 Natl. Fusarium Head Blight Forum. Michigan State University, East Lansing.

Geiser, D. M., Aoki, T., Bacon, C. W., Baker, S. E., Bhattacharyya, M. K., Brandt, M. E., Brown, D. W., Burgess, L. W., Chulze, S., Coleman, J. J., Correll, J. C., Covert, S. F., Crous, P. W., Cuomo, C. A., De Hoog, G. S., Di Pietro, A., Elmer, W. H., Epstein, L., Frandsen, R. J. N., Freeman, S., Gagkaeva, T., Glenn, A. E., Gordon, T. R., Gregory, N. F., Hammond-Kosack, K. E., Hanson, L. E., Jímenez-Gasco, M. D. M., Kang, S., Kistler, H. C., Kuldau, G. A., Leslie, J. F., Logrieco, A., Lu, G., Lysøe, E., Ma, L.-J., McCormick, S. P., Migheli, Q., Moretti, A., Munaut, F., O'Donnell, K., Pfenning, L., Ploetz, R. C., Proctor, R. H., Rehner, S. A., Robert, V. A. R. G., Rooney, A. P., Bin Salleh, B., Scandiani, M. M., Scauflaire, J., Short, D. P. G., Steenkamp, E., Suga, H., Summerell, B. A., Sutton, D. A., Thrane, U., Trail, F., Van Diepeningen, A., Vanetten, H. D., Viljoen, A., Waalwijk, C., Ward, T. J., Wingfield, M. J., Xu, J.-R., Yang, X.-B., Yli-Mattila, T., Zhang, N., and Zhang, N. 2013. One fungus, one name: Defining the genus Fusarium in a scientifically robust way that preserves longstanding use. Phytopathology 103:400-408.

Gilbert, J., Woods, S. M., and Kromer, U. 2008. Germination of ascospores of Gibberella zeae after exposure to various levels of relative humidity and temperature. Phytopathology 98:504-508.

Gourdain, E., and Rossi, V. 2011. A model to predict the risk of infection by Gibberella zeae ascospores. Page 44 in: Proc. 7th Canadian Workshop on Fusarium Head Blight. Agriculture and Agri-Food Canada, Cereal Research Centre, Winnipeg, Manitoba, Canada.

Hawksworth, D. L. 2011. A new dawn for the naming of fungi: impacts of decisions made in Melbourne in July 2011 on the future publication and regulation of fungal names. IMA Fungus 2:155-162.

Horevaj, P., Milus, E. A., and Bluhm, B. H. 2011. A real-time qPCR assay to quantify Fusarium graminearum biomass in wheat kernels. J. Appl. Microbiol. 111:396-406.

Inch, S., Fernando, D., Gilbert, J., and Tekauz, A. 2000. Relationship between environmental variables and spore release by Gibberella zeae and Fusarium graminearum. Page 29 in: Proc. 6th European Fusarium Seminar and Third Cost 835 Workshop of Agriculturally Important Toxigenic Fungi. Parey Buchverlag, Berlin, Germany.

Jennings, P., and Turner, J. A. 1996. Towards the prediction of Fusarium ear blight epidemics in the UK. Pages 233-238 in: Proc. of Brighton Crop Protection Conference: Pests and Diseases. Brighton, UK.

Jiménez, M., Manez, M., and Hernandez, E. 1996. Influence of water activity and temperature on the production of zearalenone in corn by three Fusarium species. Int. J. Food Microbiol. 29:417-421.

Jin, Y., Zhang, X., and Osborne, L. 2001. Survival of Gibberella zeae ascospores on the plant surface. (Abstr.) Phytopathology 91(suppl.):S44.

Keller, M. D., Waxman, K. D., Bergstrom, G. C., and Schmale, D. G. 2010. Local distance of wheat spike infection by released clones of Gibberella zeae disseminated from infested corn residue. Plant Dis. 94:1151-1155.

Khonga, E. B., and Sutton, J. C. 1988. Inoculum production and survival of Gibberella zeae in maize and wheat residues. Can. J. Plant Pathol. 10: 232-239.

Klittich, C. R. J., and Leslie, J. F. 1988. Nitrate reduction mutants of Fusarium moniliforme (Gibberella fujikuroi). Genetics 118:417-423.

Leong, S. L., Hocking, A. D., and Scott, E. S. 2006. Effects of water activity and temperature on the survival of Aspergillus carbonarius spores in vitro. Lett. Appl. Microbiol. 42:326-330.

Leslie, J. F., and Summerell, B. 2006. The Fusarium Laboratory Manual. Blackwell Publishing, Ames, IA.

Lysøe, E., Bone, K. R., and Klemsdal, S. S. 2009. Real-Time quantitative expression studies of the zearalenone biosynthetic gene cluster in Fusarium graminearum. Phytopathology 99:176-184.

Maldonado-Ramirez, S. L., Schmale, D. G., Shields, E. J., and Bergstrom, G. C. 2005. The relative abundance of viable spores of Gibberella zeae in the planetary boundary layer suggests the role of long-distance transport in regional epidemics of Fusarium head blight. Agric. For. Meteorol. 132: 20-27.

Manstretta, V., Gourdain, E., and Rossi, V. 2015. Deposition patterns of Fusarium graminearum ascospores and conidia within a wheat canopy. Eur. J. Plant Pathol. 143:873-880.

Manstretta, V., and Rossi, V. 2015a. Development of Fusarium graminearum perithecia in maize stalk residues as affected by temperature and moisture. Appl. Environ. Microbiol. Published online. doi:10.1128/AEM.02436-15

Manstretta, V., and Rossi, V. 2015b. Effects of weather variables on ascospore discharge from Fusarium graminearum perithecia. PLoS One 10:e0138860.

Marín, P., Jurado, M., Magan, N., Vázquez, C., and González-Jaén, M. T. 2010. Effect of solute stress and temperature on growth rate and TRIS gene 
expression using real time RT-PCR in Fusarium graminearum from Spanish wheat. Int. J. Food Microbiol. 140:169-174.

Markell, S. G., and Francl, L. J. 2003. Fusarium head blight inoculum: Species prevalence and Gibberella zeae spore type. Plant Dis. 87: 814-820.

Meier, U. 2001. Page 158 in: Growth Stages of Mono-and Dicotyledonous Plants. BBCH Monograph. Federal Biological Research Centre for Agriculture and Forestry, Berlin.

Morcia, C., Rattotti, E., Stanca, A. M., Tumino, G., Rossi, V., Ravaglia, S., Germeier, C. U., Herrmann, M., Polisenska, I., and Terzi, V. 2013. Fusarium genetic traceability: Role for mycotoxin control in small grain cereals agro-food chains. J. Cereal Sci. 57:175-182.

Nicholson, R. L., and Moraes, W. B. C. 1980. Survival of Colletotrichum graminicola: Importance of the spore matrix. Phytopathology 70:255-261.

Osborne, L. E., and Stein, J. M. 2007. Epidemiology of Fusarium head blight on small-grain cereals. Int. J. Food Microbiol. 119:103-108.

Panisson, E., Reis, E. M., and Boller, W. 2002. Quantificacao de propagulos de Gibberella zeae no ar infeccao de anteras em trigo. Fitopatol. Bras. 27:489-494.

Paul, P. A., Lipps, P. E., De Wolf, E., Shaner, G., Buechley, G., Adhikari, T., Ali, S., Stein, J., Osborne, L., and Madden, L. V. 2007. A distributed lag analysis of the relationship between Gibberella zeae inoculum density on wheat spikes and weather variables. Phytopathology 97:1608-1624.

Paulitz, T. 1999a. Epidemiology of Fusarium head blight in Eastern Canada: When and where. Pages 43-44 in: Proc. Canadian Workshop on Fusarium Head Blight, Canadian Grain Commission, Winnipeg, Manitoba, Canada.

Paulitz, T. C. 1996. Diurnal release of ascospores by Gibberella zeae in inoculated wheat plots. Plant Dis. 80:674-678.

Paulitz, T. C. 1999b. Fusarium head blight: A re-emerging disease. Phytoprotection 80:127-133.

Peixoto, J. P., and Oort, A. H. 1996. The climatology of relative humidity in the atmosphere. J. Clim. 9:3443-3463.

Pereyra, S. A., Dill-Macky, R., and Sims, A. L. 2004. Survival and inoculum production of Gibberella zeae in wheat residue. Plant Dis. 88:724-730.

Prussin, A. J. I., Qing, L., Malla, R., Ross, S. D., and Schmale, D. G. 2014a. Monitoring the long-distance transport of Fusarium graminearum from field-scale sources of inoculum. Plant Dis. 98:504-511.

Prussin, A. J. I., Szanyi, N. A., Welling, P. I., Ross, S. D., and Schmale, D. G. 2014b. Estimating the production and release of ascospores from a fieldscale source of Fusarium graminearum inoculum. Plant Dis. 98:497-503.

Ramirez, M. L., Chulze, S., and Magan, N. 2006. Temperature and water activity effects on growth and temporal deoxynivalenol production by two Argentinean strains of Fusarium graminearum on irradiated wheat grain. Int. J. Food Microbiol. 106:291-296.

Rossi, V., Pattori, E., Ravanetti, A., and Giosuè, S. 2002. Effect of constant and fluctuating temperature regimes on sporulation of four fungi causing head blight of wheat. J. Plant Pathol. 84:95-105.

Rossi, V., Ravanetti, A., Pattori, E., and Giosuè, S. 2001. Influence of temperature and humidity on the infection of wheat spikes by some fungi causing Fusarium head blight. J. Plant Pathol. 83:189-198.

Rossi, V., Terzi, V., Moggi, F., Morcia, C., Faccioli, P., Haidukowski, M., and Pascale, M. 2007. Assessment of Fusarium infection in wheat heads using a quantitative polymerase chain reaction (qPCR) assay. Food Addit. Contam. $24: 1121-1130$
Schaafsma, A. W., Tamburic-Ilincic, L., and Hooker, D. C. 2005. Effect of previous crop, tillage, field size, adjacent crop, and sampling direction on airborne propagules of Gibberella zeae/Fusarium graminearum, Fusarium head blight severity, and deoxynivalenol accumulation in winter wheat. Can. J. Plant Pathol. 27:217-224.

Schmale, D. G., and Bergstrom, G. C. 2004. Airborne propagules of Gibberella zeae: Techniques for monitoring release and viability. (Abstr.) Phytopathology 94(suppl.):S93.

Schmale, D. G., Ross, S. D., Fetters, T. L., Tallapragada, P., Wood-Jones, A. K., and Dingus, B. 2012. Isolates of Fusarium graminearum collected 40-320 meters above ground level cause Fusarium head blight in wheat and produce trichothecene mycotoxins. Aerobiologia 28:1-11.

Schmale, D. G., Shields, E. J., and Bergstrom, G. C. 2006. Night-time spore deposition of the Fusarium head blight pathogen, Gibberella zeae, in rotational wheat fields. Can. J. Plant Pathol. 28:100-108.

Schnerr, H., Niessen, L., and Vogel, R. F. 2001. Real time detection of the tri5 gene in Fusarium species by LightCycler-PCR using SYBR Green I for continuous fluorescence monitoring. Int. J. Food Microbiol. 71:53-61.

Stack, R. W. 1989. A comparison of the inoculum potential of ascospores and conidia of Gibberella zeae. Can. J. Plant Pathol. 11:137-142.

Stein, J. M., Osborne, L. E., Bondalapati, K. D., Glover, K. D., and Nelson, C. A. 2009. Fusarium head blight severity and deoxynivalenol concentration in wheat in response to Gibberella zeae inoculum concentration. Phytopathology 99:759-764.

Sung, J.-M., and Cook, R. J. 1981. Effect of water potential on reproduction and spore germination by Fusarium roseum "Graminearum", "Culmorum", and "Avenaceum." . Phytopathology 71:499-504.

Sutton, J. C. 1982. Epidemiology of wheat head blight and maize ear rot caused by Fusarium graminearum. Can. J. Plant Pathol. 4:195-209.

Terzi, V., Morcia, C., Faccioli, P., Faccini, N., Rossi, V., Cigolini, M., Corbellini, M., Scudellari, D., and Delogu, G. 2007. Fusarium DNA traceability along the bread production chain. Int. J. Food Sci. Technol. 42: 1390-1396.

Tisserat, N., and Kuntz, J. E. 1983. Longevity of conidia of Sirococcus clavigignenti-juglandacearum in a simulated airborne state. Phytopathology 73:1628-1631.

Trail, F., Xu, H., Loranger, R., and Gadoury, D. 2002. Physiological and environmental aspects of ascospore discharge in Gibberella zeae (anamorph Fusarium graminearum). Mycologia 94:181-189.

Tschanz, A. T., Horst, R. K., and Nelson, P. E. 1976. The effect of environment on sexual reproduction of Gibberella zeae. Mycologia 68:327-340.

$\mathrm{Xu}$, X.-M. 2003. Effects of environmental conditions on the development of Fusarium ear blight. Eur. J. Plant Pathol. 109:683-689.

Ye, H. Z. 1980. On the biology of the perfect stage of Fusarium graminearum Schw. Acta Phytophylacica Sin. 7:35-42.

Yoruk, E., and Albayrak, G. 2014. Tri4 and tri5 expression analysis in Fusarium graminearum and $F$. culmorum isolates by qPCR. Plant Pathol. J. 13:133-138.

Zhang, Y. J., Fan, P. S., Zhang, X., Chen, C. J., and Zhou, M. G. 2009. Quantification of Fusarium graminearum in harvested grain by real-time polymerase chain reaction to assess efficacies of fungicides on Fusarium head blight, deoxynivalenol contamination, and yield of winter wheat. Phytopathology 99:95-100. 